\title{
Service Quality of Five Star Hotels in Bangladesh: An Empirical Assessment
}

\author{
Md. Nur-E-Alam Siddique', Mst. Momena Akhter², Abdullah Al Masum ${ }^{3}$
}

${ }^{1}$ Senior Lecturer, Faculty of Business, ASA University BANGLADESH

${ }^{2 \& 3}$ Lecturer, Faculty of Business, ASA University BANGLADESH

\begin{abstract}
Although the importance of service quality and service quality measurement have been recognized, there are limited researches that have addressed the structure and antecedents of the concept for the hotel industry in Bangladesh. The clarification of the dimensions of service quality is inevitable for the managers in the hotel industry as these identify the bundles of service attributes consumers find important. Therefore, this study aims to measure the service quality from the customers' perspective of five star hotels in Bangladesh based on the SERVQUAL model. Three five star hotels (Ruposhi Bangla Hotel, Pan Pacific Sonargaon Hotel, and Radison Water Garden Hotel) out of four were selected for the purpose of the study. The study is based on the primary data collected from the respondents with the help of a self-administered questionnaire to measure the perception of service quality characteristics of the five star hotels. Data analysis has been done using SPSS software and a factor analysis has been conducted to measure the differences among the factors affecting service quality perceptions. To measure the service quality gap, five dimensions related to hotel industry were identified. The analysis shows that the service quality of the five star hotels is highly dependent on the physical appearance, interior decoration, food quality, behavior of the employees, security system, and customized services given to individual customers.
\end{abstract}

Key Words: Service Quality, Service Gap, Five Star Hotels, Perception, Bangladesh

\section{INTRODUCTION}

S ervice quality is crucial to the success of any service organization. Since customers participate in delivery and consumption of services, they interact closely with various aspects of organizations. This knowledge gives them the opportunity to assess critically the services provided in organizations (Kandampully, 2000). Customers assess service quality by comparing services they received with their desired services. Hence, service quality plays a critical role in adding value to the overall service experience (Lau et al., 2005). During the past decades, the tourism industry has become one of the most important players of economies worldwide. Travel and tourism continues to be one of the world's largest industries. The total impact of industry means that in 2011, it contributed $9 \%$ of global GDP or a value of over US\$ 6 trillion, and accounted for 255 million jobs. Over the next ten years this industry is expected to grow by an average of $4 \%$ annually, taking it to $10 \%$ of global GDP, or some US\$ 10 trillion. By 2022, it is anticipated that it will account for 328 million jobs or 1 in every 10 jobs on the planet. The direct contribution of travel and tourism to GDP of Bangladesh was BD 182.5bn (2.2\% of total GDP) in 2011, and is forecasted to rise by $6.1 \%$ pa, from $2012-$ 2022, to BDT353.7bn in 2022 (in constant 2011 prices). In 2011, travel and tourism generated 1,329,000 jobs directly $(1.9 \%$ of total employment) and this is forecast to rise by $2.9 \%$ pa over the next ten years, to 1,840,000 jobs directly. (Source: World Travel and Tourism Council: Travel \& Tourism Economic Impact 2012, Bangladesh). This important industry has many infrastructures and service institutions in its category among which the most important infrastructure is the hotel industry. The last 20 years witnessed unparalleled growth in the RMG sector, which is also the largest exporting industry in Bangladesh. Since the inception of the trade liberalization program in the early 1990's, Readymade garments accounted for Tk. 120147.3 crore $(78.40 \%)$ of the total foreign receipts in 2011-2012. Thousands of overseas apparel buyers and their representatives visit Bangladesh every year for business purpose. In addition, Cox's Bazar the largest sea beach in the world, St. Martin the one and only live coral island in the world, Sundarban the largest mangrove forest in the world are situated in Bangladesh. To see these natural beauty huge number of Asian, European, American, and Australian tourists visit Bangladesh every year. They want comfortable, luxurious, secured and world class hotel services and in most cases they choose five star hotels. To attract and satisfy the foreign guests' quality service of the hotels must be ensured. In hotel industry, service quality in terms of both customers' expectation and customers' perception could lead to customer loyalty, enhanced image, reduced costs and increased business performance (Choi \& Chu, 2001; Ramanathan \& Ramanathan, 2011). For this reason, one of the most important factors affecting hotel business performance is the improvement in service quality, which is important for creating financial benefit leading to a long-term competitive advantage for the hotel (Zhang et al., 2011).

Since service quality is an elusive concept, there is still a debate on how best to conceptualize it and how service quality can be measured in different contexts. This is because service quality constructs that are developed particularly for one culture/ industry may not be applicable in a different setting (Mattila, 1999; Hsieh and Tsai, 2009; Salazar et al., 2010). In the context of hotel industry, other attributes, such as impre- 
cise standards, short distribution channels, reliability and consistency, face-to-face interaction, and fluctuating demand, have been identified for the task of defining and measuring service quality (Akibaba, 2006; Sohrabi et al., 2012).

In addition, the demand for different hotel types in different countries is usually clustered around peak periods such as holiday seasons, which makes it difficult to provide consistent service quality measures. Beside this, the characteristics of service quality factors and service priorities, from the customers' perspective, differ depending on the hotel types. Therefore this study attempts to explore the service quality of the existing five star hotels in Bangladesh. At present there are four five star hotels in Bangladesh namely- Ruposhi Bangla Hotel, Pan Pacific Sonargaon Hotel, Radison Water Garden Hotel, and Seagull Hotel Bangladesh. The remainder of the paper is organized as follows. Section 2 reviews the literature on service quality studies in hotel industry. Section 3 focuses on the methodology used in the study. Section 4 discusses the theoretical framework. Section 5 discusses the empirical findings and section six concludes.

\section{Literature Review}

The service sector is expanding at an increasing rate and is becoming intensely competitive. Service can be defined as any activity or benefit that one party offers to another that is essentially intangible and does not result in the ownership of anything. Its production may or may not be tied to a physical product. A company's offerings often include some services (Lovelock Christopher, 2004). The nature of most services is that the customer is present in the delivery process. This means that the perception of quality is influenced not only by the 'service outcome' but also by the 'service processes. A service is activity or series of activities of more or less intangible nature that normally, but not necessarily, take place in interactions between customers and service employees and/or physical resources or goods and/or systems of the service provider, which are provided as solutions to customer problems (Fitzsimmons and Fitzsimmons, 2000). Many researchers and authors define service qualities in different ways. Service quality is a measure of how well a delivered service matches the customers' expectations. Quality in service is very important especially for the growth and development of service sector business enterprises (Powell, 1995). Service quality gap denotes the gap between customer's expectations (E) of what the service should provide and the customer's perception $(\mathrm{P})$ of what the service actually provides (Shahin, 2006). Service quality is defined as how well the service meets or exceeds the customers' expectations on a consistent basis (Parasuraman, Zeithaml and Berry, 1985). Hotels with good service quality will improve their market share and profitability (Oh and Parks, 1997).

In the face of increasing competition, the hotel business is seeking new tools to create competitive advantages. Therefore, it is putting a large amount of effort into selecting the best tools or methods to measure service quality development. In hotels, the tangible and intangible products are highly intertwined and have greater impact on guests' assessment of service quality (Alzaid and Soliman, 2002). In terms of measuring the service quality in the hotel business, SERVQUAL has been applied as a tool for understanding the factors affecting the service quality in

Copyright (C) 2013, Asian Business Consortium | ABR the hotel business, including gaps, from the customers' perspective. The outcomes of these studies have delivered contributions in relation to understanding the dimensional structure of service quality in the hotel industry. Numerous studies have postulated that service quality is multidimensional in essence for measuring hotel service quality (e.g. Knutson, et al., 1992; Amstrong et al., 1997; Choi and Chu, 1998; Ekinci \& Riley, 1998; Antilgan et al., 2003; Akibaba, 2006; Maria and Serrat, 2011).

For instance, Akibaba (2006) studied the service quality of hotels in turkey by analyzing the expectation and actual perception of service quality based on 29 characteristic indicators, which were applied from SERVQUAL, and the most important factor reflecting the overall needs of service quality was tangible services. In another study, Enz and Siguaw (2000) examined the best practices in service quality among the US hospitality industry. Only a small number of hotel operations focused specifically on service excellence, which they did extremely well for one or more service issues; creating a service culture; building an empowered service delivery system; facilitating a customer listening orientation; and developing responsive service guarantees. Wilkins et al. (2007) also studied the service quality of hotels in Australia. The seven factors were developed from SERVQUAL, covering style and convenience, room quality, special offers, quality staff, personality, fast service and quality food and beverages.

In addition, other research has indicated and explained that the characteristics of service quality factors and service priorities, from the customers' perspective, differed depending on the hotel types. However, Victorino et al. (2005) pointed out that there might have been differing service quality when dealing with hotels that serve different segments/countries, which all have different characteristics. In another study, $\mathrm{Xu}$ and Chan (2010) showed that in a specific hotel setting, some of the service quality dimensions differed from the five dimensions described in the original SERVQUAL. Mei et al. (1999) examined the dimensions of service quality in the hotel industry. They used SERVQUAL as a foundation and developed a new scale called the HOLSERV scale. As a key finding from their study, they concluded that service quality was represented by three dimensions, relating to employees, tangibility, and reliability. According to these three dimensions, the best predictor of overall service quality was employees. In a recent study, Mohsin and Lockyer (2010) assessed the service quality perception of customers of luxury hotels in India. They provided an opportunity to recognize, in ranking order, the features that are considered important by the guests staying in luxury hotels.

However, these research studies were mostly focused on Australia, Korea, The United States, and Europe. Only a minimal number of research studies related to service quality in the hospitality industry in Bangladesh context can be found throughout the review of literature. Eijaz Ahmed Khan (2008) conducted a study on service facility and customer satisfaction of the luxury hotels of Khulna city. A total number of 19 factors connected with measurement of service facility and customer satisfaction were investigated, analyzed, and evaluated. The findings indicated, as a whole, that the hotel guests' perceptions of service facility provided by the hotel industry were lower than their expectations.

This present study is an attempt to analyze the service quality 
of five star hotels in Bangladesh. For the purpose of measuring service quality of five star hotels, we have used SERVQUAL model of Parasuraman et al. (1985).

\section{Methodology}

As the study is about measuring the service quality of five star hotels, the population includes all of the five star hotels guests of six months (July, 2012 to December, 2013) in Bangladesh. However three five star hotels (Ruposhi Bangla Hotel, Pan Pacific Sonargaon Hotel, and Radison Water Garden Hotel) out of four were selected for the purpose of the study. The total valid sample size has been set at 298 and the sample was selected by using convenience sampling approach which is based on easy accessibility to the sample.

A self-administered questionnaire was applied to measure the perception of service quality based on the review of the literature on SERVQUAL and in-depth interviews with the service providers in the five star hotel industries in Bangladesh. The questionnaire was structured so that the hotel guests were asked to rate their level of agreement for the hotels at which they stayed on a five-point Likert scale ranging from (1) indicating "strongly disagree" to (5) indicating "strongly agree." Some 450 questionnaire were distributed; Hotel guests who had checked out from the hotel and were about to leave were approached. A total of 384 questionnaires were returned. Of those 298 were fully completed and usable for data analysis, representing a response rate of about 78 percent. Statistical software SPSS was used to analyze the guest perception of service quality and to classify the factors affecting service quality perception of five star hotel in Bangladesh. The secondary data were collected from various documents, reports, articles, case studies, books, and internet and so on. The collected data were analyzed keeping in mind the objective of the study. The period of study is July, 2012 to December, 2013.

Research Hypotheses

Hypotheses 1: There is no Gap between perceived services and expected services of the five star hotels in Bangladesh.

Hypotheses 2: There is no difference between the factors affecting service quality perceptions.

\section{Theoretical Framework}

For the purpose of measuring service quality of five star hotels in Bangladesh, authors have used research model of Parasuraman et al. (1985). Among the contemporary instruments for measuring service quality, SERVQUAL has got attention by the researchers in various fields including insurance, bank, education, Information Technology (IT), etc. as it deals with users views regarding services. This model is based on a comparison between the customers' expectations of the standard of service he/she will receive and his/her perception of the standard of service that is actually delivered. Furthermore, Parasuraman et al., see their service quality measurement model as one of the models that have been shown to enjoy a high degree of validity and stability. The model attempts to show the salient activities of the service organization that influence the perception of quality. Moreover, the model shows the interaction between these activities and

Copyright $@$ 2013, Asian Business Consortium | ABR identifies the linkage between the key activities of the service organization or marketer, which are pertinent to the delivery of a satisfactory level of service quality. The links are described as gaps or discrepancies; that is to say, a gap represents a significant hurdle to achieving a satisfactory level of service quality (Ghobadian et al., 1994). The SERVQUAL instrument has five dimensions or factors which are stated as follows (Iwaarden et al., 2003):

- Tangibles: physical facilities, equipment and appearance of personnel.

- Reliability: Ability to perform the promised service dependably and accurately

- Responsiveness: Willingness to help customers and provide prompt service

- Assurance: Knowledge and courtesy of employees and their ability to inspire trust and confidence.

- Empathy: Caring and individualized attention that the firm provides to its customers.

In this study 15 statements were used to measure the service quality across the above mentioned five dimensions by using five point likert scales.

\section{Findings}

\subsection{Analysis of Guest's perception of service quality and overall service quality gap}

The overall perception of service quality is presented through table 1.

Table-1: Guest's perception of service quality of five star hotels in Bangladesh

\begin{tabular}{|l|l|l|l|}
\hline Dimensions & Mean & Std. Deviation & Covariance \\
\hline Tangibility & 3.8613 & .86422 & 22.3815813 \\
\hline Assurance & 3.1040 & .81466 & 26.2454897 \\
\hline Reliability & 2.6521 & .57911 & 21.8359036 \\
\hline Responsiveness & 3.1029 & .87822 & 28.3032002 \\
\hline Empathy & 2.9620 & 1.01174 & 34.1573261 \\
\hline
\end{tabular}

From the analytical table 1 it is exposed that, guests are highly satisfied with the physical appearance, interior decoration and different classes of room facility of the five star hotels and the gusts are moderately satisfied with the behavior of the employees, quality of foods, category of service standards. In contrast the guests' satisfaction is low regarding the security, payment system, customized service and focusing on the customer needs. The overall perception of service quality is given in the following figure:

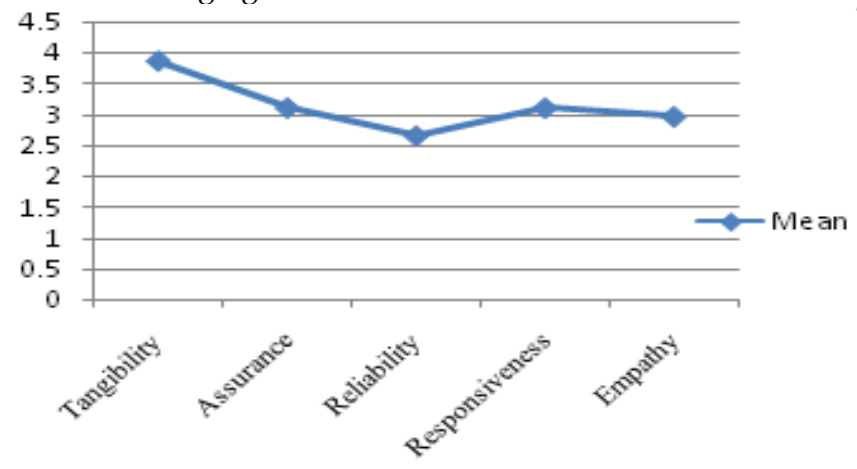

Figure 1: Overall perception of Service quality 
Table 2 reports the overall service quality gap of the five star hotels in Bangladesh. The gap score indicates the extent of gap in service. The larger the gap score is, the more is the dissatisfaction.

Table 2: Service quality gap of five star hotels

\begin{tabular}{|l|l|l|}
\hline Dimensions & Mean & Std. Deviation \\
\hline Tangibility & 1.1387 & .86422 \\
\hline Assurance & 1.8960 & .81466 \\
\hline Reliability & 2.3479 & .57911 \\
\hline Responsiveness & 1.8971 & .87822 \\
\hline Empathy & 2.0380 & 1.01174 \\
\hline
\end{tabular}

As indicated in table 2, the lowest gap is in the tangibility factors and reliability shows the highest gap. This means that the physical appearance, interior decoration, room facility etc. are good of the five star hotels in Bangladesh but problem exists in the reliability of the guests on the service of the hotels. The hotels should give more attention on giving customized service to individual guests by focusing on the needs of the guests. Overall score under each category can be presented in figure 2 to get an overall picture.

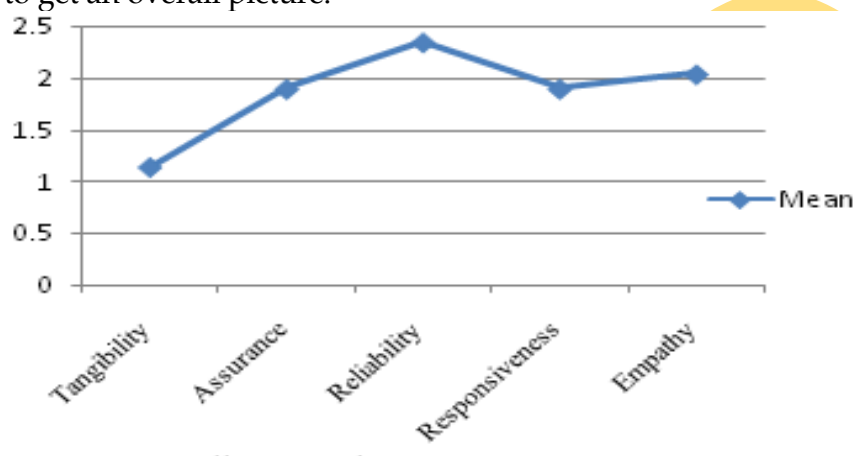

Figue 2: Overall Gap Analysis

\subsection{Factor analysis}

From the literature review, authors find out various variables which have significant influence in the perception of service quality of a five star hotel. Factor analysis is conducted on those variables. The respondent ratings are subject to principal axis factoring with varimax rotation to reduce potential multico linearity among the items and to improve reliability on the data. Fifteen items are reduced to five orthogonal factor dimensions which explained $86.328 \%$ of the overall variance indicating that the variance of original values is well captured by these five factors.

Table 3: KMO and Bartlett's Test

\begin{tabular}{|l|l|l|}
\hline \multicolumn{2}{|l|}{$\begin{array}{l}\text { Kaiser-Meyer-Olkin Measure } \\
\text { of Sampling Adequacy. }\end{array}$} & .708 \\
\hline $\begin{array}{l}\text { Bartlett's Test } \\
\text { of Sphericity }\end{array}$ & Approx. Chi-Square & 4767.754 \\
\cline { 2 - 3 } & Df & 105 \\
\cline { 2 - 3 } & Sig. & .000 \\
\hline
\end{tabular}

From the table 3, it is observed that KMO is 0.708 that is more than the required value of 0.50 . It indicates that there is no error in $70.80 \%$ of the sample and in the remaining $29.20 \%$, there may be some sort of error. Bartlett's test of sphericity indicates that the strength of relationship among the variables is highly strong. It presents good idea to proceed with factor analysis for the data.

The value of Chi-square test (4767.754 with significance level 0.000 ) signifies the rejection of null hypothesis. It means that there is a significant difference between the factors affecting service quality perceptions. Communality (see the appendix) of each statement refers to the variance being shared or common by other statements. Form the communalities it can be seen that the communality for each variable, V1 to V15 is one.

\section{Insert Table 4 here}

In table 4 , the Eigen values for the factors are, as expected, in decreasing order of magnitude as going from factor or component 1 to factor or component 15. Eigen value for a factor indicates the total variance attributed to that factor. The total variance accounted for by all 15 factors is 15 , which is equal to the number of variables. The Eigen value of factor 1, factor 2, factor 3 , factor 4 , and factor 5 are sequentially 4.350, 3.188, 2.168, 1.894 , and 1.350, which is more than the required level of 1 .

Factor 1 accounts for a variance of 4.350 which is $28.999 \%$ of the total variance. Factor 2 accounts for a variance of 3.188 which is $21.256 \%$ of total variance. Factor 3 accounts for a variance of 2.168 which is $14.452 \%$ of total variance. Factor 4 accounts for a variance of 1.894 which is $12.624 \%$ of total variance. Factor 5 accounts for a variance of 1.350 which is $8.997 \%$ of total variance. It can be interpreted that 15 variables are now reduced to 5 components or factors contributing $86.328 \%$ of the total variance, which defines that these five factors do have more variance considering the required level of $60 \%$ cumulative variance.

Table 5: Component Matrix (a)

\begin{tabular}{|c|c|c|c|c|c|}
\hline & \multicolumn{5}{|c|}{ Component } \\
\hline & 1 & 2 & 3 & 4 & 5 \\
\hline $\begin{array}{l}\text { The physical appearance of the } \\
\text { hotel is visually appealing }\end{array}$ & .691 & -.328 & -.117 & .277 & -.418 \\
\hline $\begin{array}{l}\text { The hotel has modern interior } \\
\text { decoration }\end{array}$ & .691 & -.288 & -.165 & .403 & -.382 \\
\hline $\begin{array}{l}\text { The hotel provides different } \\
\text { classes of room facility }\end{array}$ & .592 & -.053 & .100 & .556 & -.334 \\
\hline The hotel serves tasty food & .245 & .605 & .248 & .574 & .272 \\
\hline $\begin{array}{l}\text { The hotel provides errorless } \\
\text { payment system }\end{array}$ & .335 & -.427 & .777 & -.089 & .092 \\
\hline $\begin{array}{l}\text { The hotel has international } \\
\text { standard security system }\end{array}$ & .437 & -.176 & .536 & -.345 & .210 \\
\hline $\begin{array}{l}\text { The hotel provides five star } \\
\text { category service to the guests }\end{array}$ & .142 & .620 & .335 & .584 & .257 \\
\hline $\begin{array}{l}\text { The behavior of the employees } \\
\text { are satisfactory }\end{array}$ & .738 & -.334 & -.402 & -.030 & .356 \\
\hline $\begin{array}{l}\text { The hotel provides hassle free } \\
\text { service to the guests }\end{array}$ & .371 & -.364 & .778 & -.063 & .104 \\
\hline $\begin{array}{l}\text { The hotel provides customized } \\
\text { service to individual guest }\end{array}$ & .642 & .591 & .037 & -.383 & -.222 \\
\hline $\begin{array}{l}\text { The hotel provide prompt } \\
\text { service to the customers }\end{array}$ & .643 & $\mid-.121$ & -.322 & -.102 & .478 \\
\hline $\begin{array}{l}\text { Clients can trust employees } \\
\text { of the hotel }\end{array}$ & .048 & .722 & -.106 & .182 & .290 \\
\hline $\begin{array}{l}\text { Hoteliers should try knowing } \\
\text { what your needs are. }\end{array}$ & .624 & .603 & .030 & -.408 & -.164 \\
\hline $\begin{array}{l}\text { Hotelier should reply in any } \\
\text { query of the customers. }\end{array}$ & .711 & -.316 & -.411 & -.029 & .377 \\
\hline $\begin{array}{l}\text { The hotel has operating hours } \\
\text { convenient to all their customers. }\end{array}$ & .505 & .661 & .006 & -.430 & -.239 \\
\hline
\end{tabular}

Extraction Method: Principal Component Analysis.

a. 5 components extracted. 
With the help of Scree plot (see the appendix) researchers can just visualize the five factors are reduced with Eigen value greater than 1.00. Table 5 reports the factor loadings for each variable on the unrotated components or factors. Each number represents the correlation between the item and the un-rotated factor. This correlation helps to formulate an interpretation of the factors or components. It is possible to see items with large loadings (more than the required level 0.30) on several of the un-rotated factors, which makes interpretation difficult. In these cases, it can be helpful to examine a rotated solution.

Table 6: Rotated Component Matrix (a)

\begin{tabular}{|l|r|r|r|r|r|}
\hline & \multicolumn{5}{|c|}{ Component } \\
\hline & 1 & 2 & 3 & 4 & 5 \\
\hline $\begin{array}{l}\text { The physical appearance of the } \\
\text { hotel is visually appealing }\end{array}$ & .108 & .261 & .860 & .103 & -.142 \\
\hline $\begin{array}{l}\text { The hotel has modern interior } \\
\text { decoration }\end{array}$ & .054 & .284 & .900 & .032 & -.037 \\
\hline $\begin{array}{l}\text { The hotel provides different } \\
\text { classes of room facility }\end{array}$ & .058 & .061 & .828 & .127 & .275 \\
\hline The hotel serves tasty food & .113 & -.006 & .122 & .026 & .928 \\
\hline $\begin{array}{l}\text { The hotel provides errorless } \\
\text { payment system }\end{array}$ & -.071 & .004 & .139 & .942 & -.046 \\
\hline $\begin{array}{l}\text { The hotel has international } \\
\text { standard security system }\end{array}$ & .234 & .209 & -.059 & .753 & -.048 \\
\hline $\begin{array}{l}\text { The hotel provides five star } \\
\text { category service to the guests }\end{array}$ & .071 & -.120 & .072 & .057 & .946 \\
\hline $\begin{array}{l}\text { Responsiveness: The behavior } \\
\text { of the employees are satisfactory }\end{array}$ & .062 & .922 & .282 & .075 & -.087 \\
\hline $\begin{array}{l}\text { The hotel provides hassle free } \\
\text { service to the guests }\end{array}$ & -.032 & .014 & .151 & .931 & .018 \\
\hline $\begin{array}{l}\text { The hotel provides customized } \\
\text { service to individual guest }\end{array}$ & .954 & .114 & .130 & .064 & .129 \\
\hline $\begin{array}{l}\text { The hotel provide prompt } \\
\text { service to the customers }\end{array}$ & .151 & .857 & .063 & .076 & .057 \\
\hline $\begin{array}{l}\text { Clients can trust employees } \\
\text { of the hotel }\end{array}$ & .290 & .061 & -.216 & -.301 & .654 \\
\hline $\begin{array}{l}\text { Hoteliers should try knowing } \\
\text { what your needs are. }\end{array}$ & .948 & .142 & .070 & .064 & .141 \\
\hline $\begin{array}{l}\text { Hotelier should reply in any } \\
\text { query of the customers. }\end{array}$ & .053 & .918 & .252 & .056 & -.072 \\
\hline $\begin{array}{l}\text { The hotel has operating hours } \\
\text { convenient to all their customers. }\end{array}$ & .960 & .025 & .024 & -.023 & .111 \\
\hline Extraction Methe & $C .07$ & & & & \\
\hline
\end{tabular}

Extraction Method: Principal Component Analysis. Rotation Method: Varimax with Kaiser Normalization.

a Rotation converged in 6 iterations.

The rotated factor matrix (table 6) makes it simple for taking decisions. Factor 1 has a deep relationship with variable 10, 13 , and 15; factor 2 has relationship with 8,11, and 14; factor 3 has relationship with 1,2, and 3; factor 4 has relationship with 5, 6, and 9; and factor 5 has relationship with variable 4, 7 , and 12 . The highest loading of each variable is categorized under each factor.

Factor 1 includes customized service provided to individual guest, focusing on the need of the guest, and operating hours convenient to all the guests which can be broadly defined as empathy. Factor 2 includes the behavior of the employees, promptness in providing service, and responsiveness in any query of the customers which can be broadly defined as responsiveness. Factor 3 includes the physical appearance, interior decoration, and different classes of room facilities and it can be categorized as tangibility of the service provided by the five star hotels. Factor 4 includes the reliability factors in serving the guests and factor 5 includes the factors related to assurance of service quality by the five star hotels in Bangladesh.

\section{CONCLUSION}

Service firms in the developing country like other organizations are now realizing the significance of customer oriented philosophies and turning to quality management approaches to facilitate managing their business. The research on service quality of five star hotels in Bangladesh shows that the service providers of the five star hotels in Bangladesh are more or less aware about the quality of service. One of the primary causes of service quality design failure is the lack of understanding of the evolving need and preferences of the targeted customers. The five star hotels may attempt to move itself by reshuffle its service delivery system to enhance the service quality. Dimension of SERVQUAL items such as providing customized service, service delivery on time, modern interior decoration, providing international standard security system, tasty food, quick response to gusts' problems, personal attention and understanding of the needs of the guests appear to be fertile areas for future inquiry. The key finding from our study is that the service quality of the five star hotels in Bangladesh is moderate. So, the five star hotels in Bangladesh should take proper steps to ensure the guest's satisfaction on their service through reliable service and giving assurance to fulfill their expected requirements. Finally, as a caveat, the results of this research should be interpreted with great caution since previous research differs substantially across different measurement procedures. In this study the researchers have measured the service quality to identify the problems but no solution has been given to solve the problems. Further study should focus on the customer satisfaction and quality improvement of the five star hotels in Bangladesh.

\section{REFERENCES}

Akibaba, A. (2006). Measuring service quality in the hotel industry: a study in a business hotel in Turkey. Hospitality Management, 170192

Alzaid, A.A. \& Soliman, A.A. (2002). Service quality in Riyadh's Elite hotels: measurement and evaluation. J. King saud.Univ. Admin. Sci 14(2), 83-103.

Amstrong, R., Connie, M., \& Go, F. (1997). The importance of crossculture expectations in the measurement of service quality perceptions in the hotel industry. International Journal of Hospitality Management, 16(2), 181-190.

Antilgan, E., Akinci, S., \& Aksoy, S. (2003). Mapping service quality in the tourism industry. Managing Service Quality, 13(2), 412-422.

Choi, T.Y., \& Chu, K. S. (1998). Consumer perceptions of the quality of service in three hotel categories in Hong Kong. Journal of Vacation Marketing, 5(2), 176-189.

Choi, T.Y., \& Chu, R. (2001). Determinants of hotel guests' satisfaction and repeat patronage in the Hong Kong hotel industry. Journal of Vacation Marketing, 20, 277-297

Ekinci, Y., \& Riley, M. (1998). A critique of the issues and theoretical assumptions in service quality measurement in the lodging industry: time to move the goal-posts?, Hospitality Management, $17,349-362$

Enz, C.A., \& Siguaw, J.A. (2000). Best practices in service quality. Cornell Hotel E Restaurant Administration Quarterlt, 41(5), 20-29.

Fitzsimmons, J.A., \& Fitzsimmons, M.J. (2000). Service Management: Operations, Strategy, and Information Technology. Singapore: Mc 
Graw-Hill.

Ghobadian Abby, Speller Simon, \& Jones Matthew. (1994). Service quality: concepts and models. International Journal of Quality and Reliability Management, 11(9), pp. 43-66.

Hsieh, A., \& Tsai, C. (2009). Does national culture really matter? Hotel service perceptions by Taiwan and American tourists. International Journal of Culture, Tourism, and Hospitality Research, 23(1), 54-69.

http://www.southtravels.com/asia/bangladesh/5star.html

Kandampully, J. (2000). The impact of demand fluctuation on the quality of service: A tourism industry example. Managing Service Quality, 10(1), 10-18

Khan, A.E. (2008). Measuring service facility and customer satisfaction of the luxury hotels of Khulna. Khulna University Business Review, Vol. 6 No. 1E2, pp. 49-61

Khutson, B., Stevens, P., Patton, M., \& Thomson, C. (1992). Consumers' expectations for service quality in economy, mid-priced and luxury hotels. Journal of Hospitality and Leisure Marketing, 1(2), 27-43

Lau, P.M., Khatibi, A.A. \& Fie, D.Y.G. (2005). Service Quality: A study of the luxury hotels in Malaysia. Journal of American Academy of Business, Cambridge, 7(2), 46-55.

Lovelock, Christopher, \& Jochen Wirtz. (2004). Service Marketing: People, Technology, Strategy. Singapore: Pearson Education Pte. Ltd., $5^{\text {th }}$ edition, pp. 406-411.

Maria, J., Serrat, B. (2011). Quality of hotel service and customer protection: A European contract law approach. Tourism Management, 32(2), 277-287.

Mattila, A.S. (1999). The role of culture in the service evaluation process. Journal of Service Research, 1(3), 250-261.

Mei, A.W.O., Dean, A.M., \& White, C.J. (1999). Analyzing service quality in the hospitality industry. Managing Service Quality, 9(2), 136-14.

Mohsin, A., \& Lockyer, T. (2010). Customer perceptions of service quality in luxury hotels in New Delhi, India: an exploratory study. International Journal of Contemporary Hospitality Management, 22(2), 160-173.

Oh, H., and Parks, S.C. (1997). Customer satisfaction and service quality: A critical review of the literature and research implications for the hospitality industry. Hospitality Research Journal, 20(3), 35-64.

Parasuraman, A., Zeithaml, V.A. and Berry, L.L. (1985). A conceptual model of service quality and its implication. Journal of marketing,
Vol.49, fall, pp. 41-50.

Powell, T.C. (1995). Total Quality Management as Competitive Advantage: A Review and Empirical Study. Strategic management Journal, Vol.16, pp. 15-37

Ramanathan, U., \& Ramanathan, R. (2011). Guests' perceptions on factors influencing customer loyalty: An analysis for UK hotels. International Journal of Contemporary Hospitality Management, 23(1), 7-25.

Salazar, A., Xosta, J., \& Rita, P. (2010). A service quality evaluation scales for the hospitality sector: Dimensions, attributes and behavioral intentions. Worldwide Hospitality and Tourism Themes, 2(4), 46-57.

Shahin, A. (2006). SERVQUAL and model of service quality gaps: A framework for determining and prioritizing critical factors in delivering quality services. In: Service quality- An introduction. Partha Sarathy V. (Ed.). Andhra Pradesh: ICFAI University Press, 117-131.

Sohrabi, B., Vanani, I.R., Tahmaswbipur, K., \& Fazil, S. (2012). An exploratory analysis of hotel selection factors: A comprehensive survey of Tehran hotels. International Journal of Hospitality Management, 31(1), 96-106.

Van Iwaarden, J., Van Der Wiele, T., ball, L., \& Millen, R. (2003). Applying SERVQUAL to web sites: An exploratory study. International Journal of Quality and Reliability Management, 20(8), 919-935.

Victorino, L., Verna, R., Plaschka, G., \& Dev, C. (2005). Service innovation choices in the hospitality industry. Managing Service Quality, 15(6), 555-576.

Wilkins, H., Merrilees, B., \& Herington, C. (2007). Towards an understanding of total service quality in hotels. International Journal of Hospitality Management, 26(4), 840-853.

www.wttc.org/site_media/uploads/downloads/bangladesh2012.pdf

Xu, J.B., \& Chan, A. (2010). A conceptual framework of hotel experience and customer-based brand equity: some research questions and implications. International Journal of Contemporary Hospitality Management, 22, 174-193.

Zhang, Z., Ye, Q., \& Law, R. (2011). Determinants of hotel room price: An exploration of travelers' hierarchy of accommodation needs. International Journal of Contemporary Hospitality Management, 23(7), 972-981.

$--0$

Table 4: Total Variance Explained

\begin{tabular}{|c|c|c|c|c|c|c|c|c|c|}
\hline \multirow[t]{2}{*}{ Component } & \multicolumn{3}{|c|}{$\begin{array}{c}\text { Initial Eigen } \\
\text { values }\end{array}$} & \multicolumn{3}{|c|}{$\begin{array}{l}\text { Extraction Sums of } \\
\text { Squared Loadings }\end{array}$} & \multicolumn{3}{|c|}{$\begin{array}{l}\text { Rotation Sums of } \\
\text { Squared Loadings }\end{array}$} \\
\hline & Total & $\begin{array}{c}\% \text { of } \\
\text { Variance }\end{array}$ & $\begin{array}{c}\text { Cumulative } \\
\%\end{array}$ & Total & $\begin{array}{c}\% \text { of } \\
\text { Variance }\end{array}$ & $\begin{array}{c}\text { Cumulative } \\
\%\end{array}$ & Total & $\begin{array}{c}\% \text { of } \\
\text { Variance }\end{array}$ & $\begin{array}{c}\text { Cumulative } \\
\%\end{array}$ \\
\hline 1 & 4.350 & 28.999 & 28.999 & 4.350 & 28.999 & 28.999 & 2.940 & 19.598 & 19.598 \\
\hline 2 & 3.188 & 21.256 & 50.255 & 3.188 & 21.256 & 50.255 & 2.675 & 17.831 & 37.430 \\
\hline 3 & 2.168 & 14.452 & 64.707 & 2.168 & 14.452 & 64.707 & 2.516 & 16.776 & 54.205 \\
\hline 4 & 1.894 & 12.624 & 77.331 & 1.894 & 12.624 & 77.331 & 2.466 & 16.442 & 70.648 \\
\hline 5 & 1.350 & 8.997 & 86.328 & 1.350 & 8.997 & 86.328 & 2.352 & 15.680 & 86.328 \\
\hline 6 & .578 & 3.856 & 90.183 & & & & & & \\
\hline 7 & .436 & 2.910 & 93.093 & & & & & & \\
\hline 8 & .336 & 28.999 & 95.332 & & & & & & \\
\hline 9 & .266 & 1.772 & 97.104 & & & & & & \\
\hline 10 & .147 & .978 & 98.081 & & & & & & \\
\hline 11 & .091 & .607 & 98.688 & & & & & & \\
\hline 12 & .073 & .488 & 99.175 & & & & & & \\
\hline 13 & .065 & .433 & 99.608 & & & & & & \\
\hline 14 & .042 & .279 & 99.888 & & & & & & \\
\hline 15 & .017 & .112 & 100.000 & & & & & & \\
\hline
\end{tabular}

Extraction Method: Principal Component Analysis. 